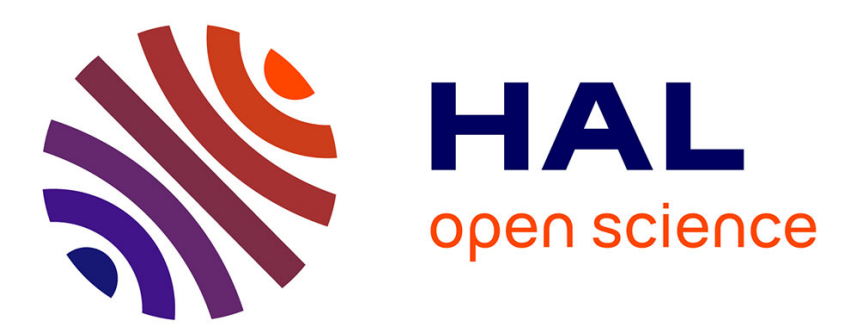

\title{
Enhanced photobactericidal and targeting properties of a cationic porphyrin following attachment of Polymyxin B
}

Florent Le Guern, Vincent Sol, Catherine Ouk, Philippe Arnoux, Céline Frochot, Tan-Sothea Ouk

\section{- To cite this version:}

Florent Le Guern, Vincent Sol, Catherine Ouk, Philippe Arnoux, Céline Frochot, et al.. Enhanced photobactericidal and targeting properties of a cationic porphyrin following attachment of Polymyxin B. Bioconjugate Chemistry, 2017, 28 (9), pp.2493 - 2506. 10.1021/acs.bioconjchem.7b00516 . hal01710928

\section{HAL Id: hal-01710928 \\ https://hal.univ-lorraine.fr/hal-01710928}

Submitted on 16 Feb 2018

HAL is a multi-disciplinary open access archive for the deposit and dissemination of scientific research documents, whether they are published or not. The documents may come from teaching and research institutions in France or abroad, or from public or private research centers.
L'archive ouverte pluridisciplinaire $\mathbf{H A L}$, est destinée au dépôt et à la diffusion de documents scientifiques de niveau recherche, publiés ou non, émanant des établissements d'enseignement et de recherche français ou étrangers, des laboratoires publics ou privés. 


\section{Enhanced photobactericidal and targeting properties of a cationic porphyrin following attachment of Polymyxin B}

Florent Le Guern, ${ }^{\dagger}$ Vincent Sol, ${ }^{+*}$ Catherine Ouk, ${ }^{\S}$ Phillipe Arnoux, ${ }^{\ddagger}$ Céline Frochot, ${ }^{\ddagger}$ TanSothea Ouk ${ }^{+*}$

†Université de Limoges, Laboratoire de Chimie des Substances Naturelles, EA 1069, 123

Avenue Albert Thomas, 87060 Limoges Cedex, France.

${ }^{\S}$ Université de Limoges, BISCEm, 87000 Limoges, France

tUniversité de Lorraine, Laboratoire Réactions et Génie des Procédés (LRGP), UMR 7274 CNRS, ENSIC, 1 rue Grandville, 54000 Nancy, France

KEYWORDS. PACT, cationic porphyrin, polymyxin B, targeting, thiol-click, antimicrobial peptide 


\section{ABSTRACT.}

A novel compound, consisting of a cationic porphyrin covalently attached to a derivative of polymyxin B has been synthesized, which presents enhanced activity and targeting properties compared to usual cationic porphyrins recognized as efficient photosensitizers in PACT. A synthesis pathway was established to preserve the bactericidal activity of the peptide. Accordingly, the N-terminal amino acid (L-2,4-diaminobutyric acid) of polymyxin B (PMB) was switched for a cysteine residue. Then, the resulting derivative of PMB was covalently bound to 5-(4-aminophenyl)-10,15,20-tri(4- $N$-methylpyridyl)-21H,23H-porphyrin using a thiolmaleimide "click" coupling. The peptide-coupled photosensitizer has demonstrated an improved PACT efficiency compared to the cationic porphyrin alone. This enhancement has been observed against Staphylococcus aureus, Pseudomonas aeruginosa, and especially Escherichia coli. Flow cytometry analyses and confocal imaging microscopy demonstrated that the porphyrin-peptide conjugate selectively sticked to the cell walls of either Gram+ or Grambacteria, thus justifying the damages induced by singlet oxygen production.

\section{INTRODUCTION.}

Chronic wound infection represents a worldwide problem of public health. Besides leading to frequent delay in wound healing, infected wounds are responsible for considerable morbidity and mortality and are associated with increasing healthcare costs ${ }^{1}$. The emergence of MultiDrug Resistant (MDR) bacteria renders the management of infected chronic wounds ever more challenging. Moreover, evidences suggest that bacterial biofilm play significant roles in the inability of chronic wounds to heal ${ }^{2,3}$. When subcutaneous tissues are exposed to the environment, they become vulnerable and can be contaminated by microorganisms from the 
surroundings or from the skin microbiome (i.e. Staphylococcus epidermidis or Corynebacterium sp. $)^{4,5}$. Gram-negative bacteria (Pseudomonas aeruginosa, Escherichia coli and Acinetobacter baumanii) tend to appear in the upper layers of open wounds a few weeks after initiation. Even if they are unable to reach deeper tissues, they increase the wound microbial burden and pathogenicity $^{6-8}$.

The emerging ineffectiveness of regular treatments has promoted the study of other strategies which would be able to reduce the impact of microbial infections. Around the world, laboratories are turning their attention towards a recent and promising alternative to antibiotics (in particular for the treatment of superficial infections), namely photodynamic antimicrobial chemotherapy (PACT). This technique relies on the photochemical activation of photosensitizers (PS) in presence of dioxygen $\left({ }^{3} \mathrm{O}_{2}\right)$. Under appropriate light irradiation, PS activation leads to the production of singlet oxygen $\left({ }^{1} \mathrm{O}_{2}\right)$ by energy transfer, or oxygen radicals by electron transfer. These species are called reactive oxygen species (ROS) and are able to rapidly react with a large panel of molecules (proteins, lipids, nucleic acids) ; the number and diversity of the cellular damages greatly limit the rise of bacterial strains that resist to this treatment ${ }^{9,10}$. Owing to their very short life span, ROS do not end up in the waste system unlike common sanitizers, and are thus environmentally friendly ${ }^{9,11}$. PACT was first tried out against methicillin-resistant S. aureus (MRSA), with promising results ${ }^{12}$. Unfortunately, Gram-negative bacteria have shown a poor sensitivity to the firstly studied PS, mainly due to their outer membrane ${ }^{13,14}$. Although PACT exhibits many advantages for bacterial photoinactivation, its lack of specificity is a major drawback, since it causes damages to the host tissues as well ${ }^{15}$. On the other hand, it has been shown that cationic PS exhibited a good affinity for bacteria by interacting through electrostatic interactions, with the highly negatively charged cell wall components such as lipoteichoic acid 
(LTA) in Gram-positive and lipopolysaccharide (LPS) in Gram-negative bacteria ${ }^{16-18}$. Unfortunately, the phospholipid species of the mammalian cells may also interact with cationic PS. Even if adsorptive endocytosis is a slow process, the interaction between the PS and the bacteria has to be as strong as possible in order to reduce unwanted effects on mammalian cells $^{19}$. Nevertheless, cationic porphyrins displayed photoinduced activity against a broad spectrum of bacteria ${ }^{18,20}$, and this trend was also confirmed with several families of cationic PS $^{21-23}$. Despite their affinity for bacteria, such PS do not present a very strong interaction with Gram-negative bacteria and bacteria-absorbed PS can be easily washed out ${ }^{24}$. Moreover, a very high effective dose of PS may be required to photoinactivate a few resilient species, like $P$. aeruginosa. These two major issues may lead to damages to human cells, thus hampering treatment of infected wound by means of PACT.

Polymyxins represent a group of polypeptide antibiotics, produced by several strains of Paenibacillus polymyxa ${ }^{25}$. Polymyxins consist of 10 amino acid residues, with a heptapeptide ring, and a linear tripeptide acylated by a fatty acid at its amino terminus (Figure 1). Five $L$ diaminobutyric acid ( $L$-Dab) residues, positively charged, are found in positions $1,3,5,8$ and $9^{26}$. Initially, polymyxins included 5 different molecules (named Polymyxin A to E), but nowadays, only two of them (B and E, also known as colistin) are used in clinical practice. The difference between these two peptides is based on the sixth amino acid: $D$-phenylalanine for polymyxin B and D-leucine for colistin. The variation of the lipophilic "tail" leads to subfamilies 1 to 4 according to their length and ramification. Generally, commercial polymyxin B (PMB) is a mixture mainly composed of $\mathrm{PMB}_{1}$ and $\mathrm{PMB}_{2}$. These antimicrobial peptides are selective and used to fight Gram-negative bacteria due to the electrostatic interaction between their $\gamma$-amine functions and the negatively charged phosphate headgroups of Lipid $\mathrm{A}^{23,27}$. Known 
as the "last-line" treatment against Gram-negative resistant strains, polymyxins are becoming increasingly common ${ }^{28}$. In 2016, the first colistin-resistant E. coli strain showed up in a medical environment ${ }^{29}$.

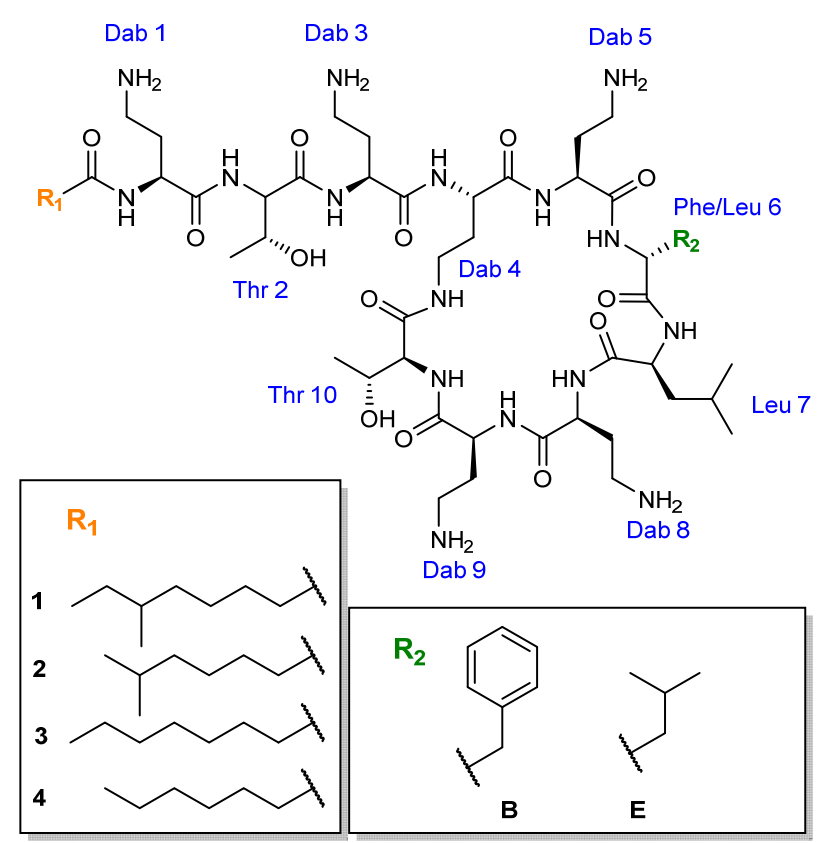

Figure 1. General structure of Polymyxins. The 10 amino acid sequence, with a cyclisation between residues 4 and 10 , composes the hydrophilic "head", whereas $\mathrm{R}_{1}$ is related to the lipophilic "tail". Polymyxins are named E or B, depending on the sixth residue $\left(\mathrm{R}_{2}\right)$.

Different approaches have been developed in order to improve PACT ${ }^{30}$ : addition of targeting agents as a peptide ${ }^{24}$ or a cationic polymer ${ }^{31,32}$, or the use of a disrupting membrane agent as EDTA $^{33}$ or an antibiotic ${ }^{34}$. In a previous study, Dosselli and co-workers designed a new type of conjugates by covalent attachment of the antimicrobial peptide apidaecin $1 \mathrm{~b}$ to a cationic porphyrin in order to improve the efficiency and the targeting of the latter ${ }^{24}$. Despite an interesting result obtained with another conjugate consisting of a neutral porphyrin, the cationic porphyrin-peptide conjugate for its part has shown an attenuation of the photobactericidal 
activity and a lack of specific interaction. Promising results were then obtained with a neutral porphyrin conjugated to YI13WF or buforin antimicrobial peptides ${ }^{35,36}$. Nonetheless, no such trend was observed with conjugates based on cationic porphyrin. On the other hand, Nitzan and co-workers have demonstrated that PMB has the ability to increase the effect of PACT on Gramnegative bacteria by disorganizing bacterial membranes ${ }^{34}$. In addition, polymyxin-dansyl probing has been studied by Deris and co-workers ${ }^{37}$, demonstrating that the interaction of polymyxin with LPS is mildly influenced by the coupling with a fluorophore.

In the present work, and in connection with our research program in PACT, we report the synthesis and characterization of a novel cationic porphyrin-polymyxin B conjugate (5, Figure 2) along with a study of its photobactericidal properties against Gram-positive and Gram-negative bacteria. A "thiol-ene click" reaction allowed us to covalently bind a cationic photosensitizer to a modified peptide, in clean and soft conditions (PBS medium, without catalyst). The conjugate has shown promising results which indicate an enhanced photoactivity and targeting towards Gram-negative bacterial strains and, surprisingly, towards a Gram-positive strain as well. 


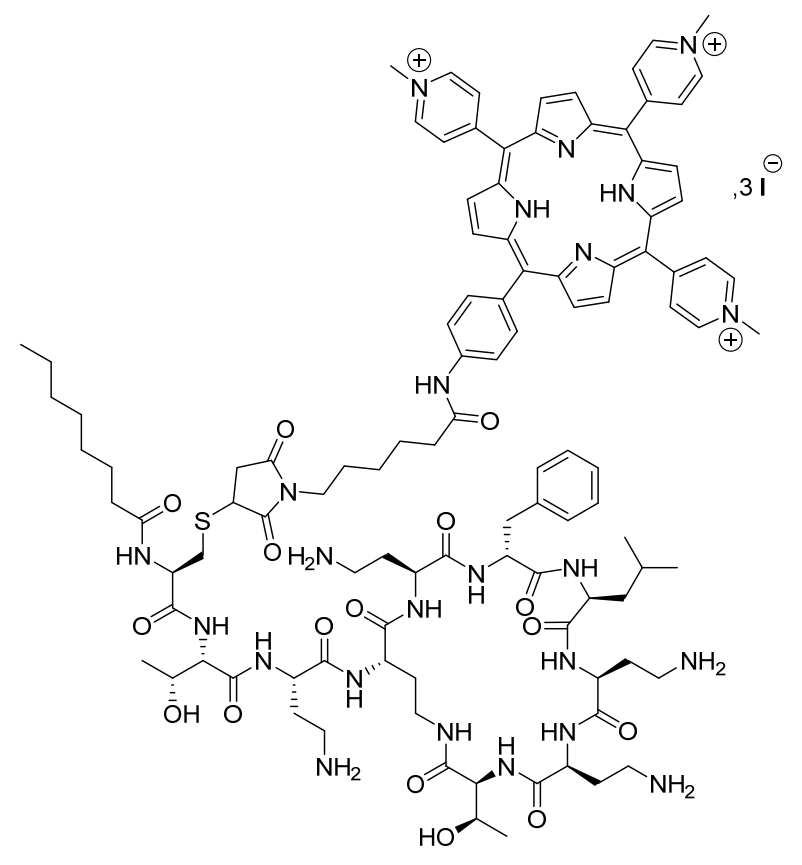

Figure 2. Chemical structure of the cationic porphyrin-polymyxin B conjugate (5).

RESULTS AND DISCUSSION.

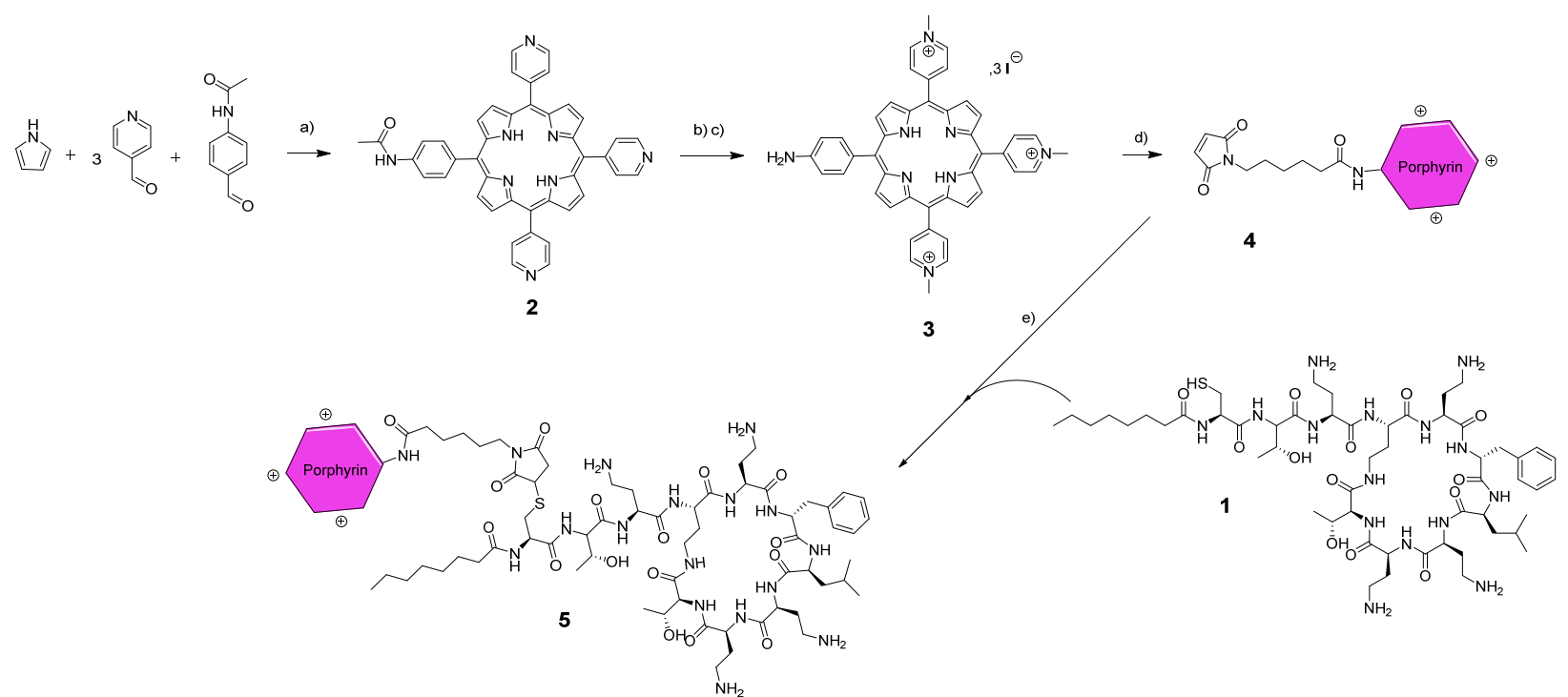

Scheme 1. Synthetic route of cationic porphyrin-Polymyxin B conjugate (5). a) Propionic acid, 3

h, $140{ }^{\circ} \mathrm{C}$. b) Iodomethane, anhydrous DMF, 1 h, $140{ }^{\circ} \mathrm{C}$. c) $25 \% \mathrm{TFA} / \mathrm{H}_{2} \mathrm{O}, 5$ h, $100{ }^{\circ} \mathrm{C}$. d) 6maleimidohexanoic acid, HCTU, DIEA, anhydrous DMF, 24 h, RT. e) PBS pH 6.5, 24 h, RT. 
Synthesis and characterization of the conjugate. The purpose of this study is to ensure the targeting of Lipid A of the outer membrane of Gram-negative bacteria. Thus, we decided to favor a synthesis pathway based on an active polymyxin (in opposition to the polymyxin nanopeptide $^{34}$ ) as its antimicrobial power is undoubtedly related to this target (Scheme 1). Moreover, results obtained with a conjugate based on an inactive polymyxin derivative must been interpreted with caution ${ }^{39}$. Thus, the synthesis pathway was based on the creation of an efficient derivative of polymyxin carrying a thiol function, because this function provides a chimio-specific reaction since polymyxins contain a consequent number of primary amine and hydroxyl groups. In addition, the review by Velkov and co-workers ${ }^{40}$ established the involvement of each amino acid in the bactericidal activity, then the ability to target lipid A. According to another communication by Kanazawa and co-workers ${ }^{41}$, the modification of residues 1 or 3 only led to a mild decrease of antimicrobial activity. Otherwise, a specific Michael addition reaction between a thiol and a maleimide function, known as thiol-maleimide “click" coupling, could be considered ${ }^{42,43}$. As the synthesis of a porphyrin derivative carrying a maleimide function was totally feasible, the first amino acid of the polymyxin primary structure was switched for a $L$-cysteine. Moreover, click "thiol-maleimide" reaction prevents the use of catalysts and the needs of large amounts of porphyrin. A trityl protecting group was chosen for this amino acid in order to anticipate an unexpected but potential reaction of primary amines with maleimide, as the deprotection of trityl group can be carried out without modification of the Boc functions protecting the Dab amino acid residues.

According to previous studies ${ }^{38,44}$, the synthesis protocol of polymyxin derivative 1 was slightly modified (Figure S1). Apart from the modification of the primary structure, the synthesis only differs at the deprotection step of the Dde group. Whereas this reaction is usually managed by 
action of hydrazine on the protecting group, a mixture of hydroxylamine and imidazole is also efficient, according to a study by Diaz-Mochon and co-workers ${ }^{44}$. Moreover, contrary of hydrazine, these reagents are unable to reduce the allyl group located on the first grafted amino acid residue and allow to work in safe conditions. Porphyrin $\mathbf{2}$ was successfully prepared using the Little ${ }^{45}$ condensation and was obtained, after purification by column chromatography, with $2 \%$ yield. In this strategy, we have chosen first to alkylate meso-pyridyl substituents with an excess amount of methyl iodide. Then, in order to obtain compound $\mathbf{3}$ which carries a primary amine, the crude product was directly hydrolyzed with an acidic solution made of $T F A / \mathrm{H}_{2} \mathrm{O}$ (25/75, v/v). 3 and 6-maleimidohexanoic acid were bound through amide formation using an excess of (2-(6-chlor-1H-benzotriazol-1-yl)-1,1,3,3-tetramethylaminium-hexafluorophosphate (HCTU) and N,N-diisopropylethylamine (DIEA) in anhydrous DMF at room temperature. After purification by reverse phase chromatography, compound 4 was obtained with only $30 \%$ yield. A low yield was obtained for this synthesis despite the usual good reactivity of uronium salt. In fact, the final product was hardly extracted from remaining reactants and other benzotriazole derivatives. Some improvements are currently in progress in order to increase the yield of this step by using other catalyst and/or a different purification protocol (e.g. by the means of preparative HPLC). In order to obtain the final product 5, a phosphate buffer solution at $\mathrm{pH} 6.5$ was chosen, since the usual optimal $\mathrm{pH}$ for such reaction lies between 6.5 and 7.5. Since their pKa are higher than $7.5^{28}$, primary amines are not supposed to react with maleimide. Furthermore, a pH 6.5 solution may also ensure a better stability of the polymyxin derivatives $^{46,47}$. As previously advised, using quality composites (as HPLC-grade) should also increase the yield of the final reaction, even if the outlined yield can already be considered as sufficient. The molecular weight and the isotopic profile of compound $\mathbf{5}$ retrieved from HRMS 
allowed the establishment of the chemical formula which is consistent with the expected product (Figure S6). All the products were individually characterized by means of ${ }^{1} \mathrm{H}$ NMR spectroscopic analyses in $\mathrm{DMSO}_{\mathrm{d} 6}(500 \mathrm{MHz})$. In addition to satisfying results from $\mathrm{MS}$ analyses $(\mathrm{ESI}+)$, the ${ }^{1} \mathrm{H}$ NMR spectra of $\mathbf{2}$ and $\mathbf{3}$ are consistent with the literature (respectively Figure S3 and S4). Using the data obtained with compound 3, each peak from the ${ }^{1} \mathrm{H}$ NMR spectrum of 4 (Figure S5) has been assigned to the protons in the molecule (especially for those of the maleimide function at $7.05 \mathrm{ppm}) .{ }^{1} \mathrm{H}$ NMR spectrum of conjugate $\mathbf{5}$ is in accordance with the superposition of $\mathbf{1}$ and $\mathbf{4}$ spectra, excepted for the peak assigned to the protons of the maleimide function whose signals have been shifted, due to the coupling reaction. Complementary analyses as ${ }^{1} \mathrm{H}$ COSY, TOCSY allowed to check the chimio-specificity of the coupling reaction. A first argument is based on the persistence of the peaks of the primary amine protons, in spite of the coupling $(\sim 7.7 \mathrm{ppm})$, which indicates that these functions did not react with maleimide. A second confirmation was obtained through ${ }^{1} \mathrm{H}$ COSY and TOCSY spectra allowing the retrieval of the peaks, as well as the $J$-couplings, due to the conjugated maleimide and cysteine residue. Thus, the structure of the final compound $\mathbf{5}$ was confirmed.

Photophysical properties of the conjugate. Compounds $\mathbf{2}$ to $\mathbf{5}$ show typical UV-vis absorption spectra which comprise a Soret band around $420 \mathrm{~nm}$ and four less intense Q bands (Figure S8). In order to correlate the following biological assays, the photophysical properties of conjugate 5 had to been investigated through a comparison with another cationic porphyrin and further studies in aqueous solution. Unfortunately, the photophysical attributes of $\mathbf{3}$ could not be obtained, because of the lone electron pair of nitrogen leading to a quenching of fluorescence and phosphorescence of the porphyrin core in pure solvents ${ }^{48}$. Thus, 5-10,15,20-tetrakis $(4-\mathrm{N}$ methylpyridyl)-21H,23H-porphyrin (TMPyP) was chosen as a standard, because of its 
established properties ${ }^{49}$. For these analyses, deuterium oxide was used, as the biological assays have been tried out in aqueous solutions, and because this solvent allows the establishment of singlet oxygen quantum yield by direct observation of phosphorescence at $1275 \mathrm{~nm}^{50}$. Absorption, fluorescence, and phosphorescence spectra $\left(\lambda_{\operatorname{exc}}=425 \mathrm{~nm}\right)$ are presented in Figure 3 (respectively A, B and C). Absorption spectra of the two PS show a similar profile in spite of a weak redshift of all bands of 5. Whereas TMPyP presents a broadened fluorescence spectrum (well-known from the literature ${ }^{17}$ ), the coupling with the peptide leads to a partial recovery of the two usual bands observed for porphyrins (664 and $717 \mathrm{~nm}$ ), probably due to its better solubility in comparison with TMPyP. The fluorescence quantum yield and lifetime of both PS are relatively similar (Table 1). These molecules have been tested for their ability to produce singlet oxygen in $\mathrm{D}_{2} \mathrm{O}$. Based on the literature, the singlet oxygen quantum yield of TMPyP $\left(\Phi_{\Delta}\left(\mathrm{D}_{2} \mathrm{O}\right)=0.90\right)$ allowed us to estimate the conjugate's yield $\left(\Phi_{\Delta}=0.79\right)$. Despite this slight discrepancy between the two PSs, the yields and the lifetimes are consistent with the literature $^{51,52}$. According to this photophysical characterization, a potentially enhanced photobactericidal activity brought by the peptide coupling could not be attributed to a stronger production of ROS. 

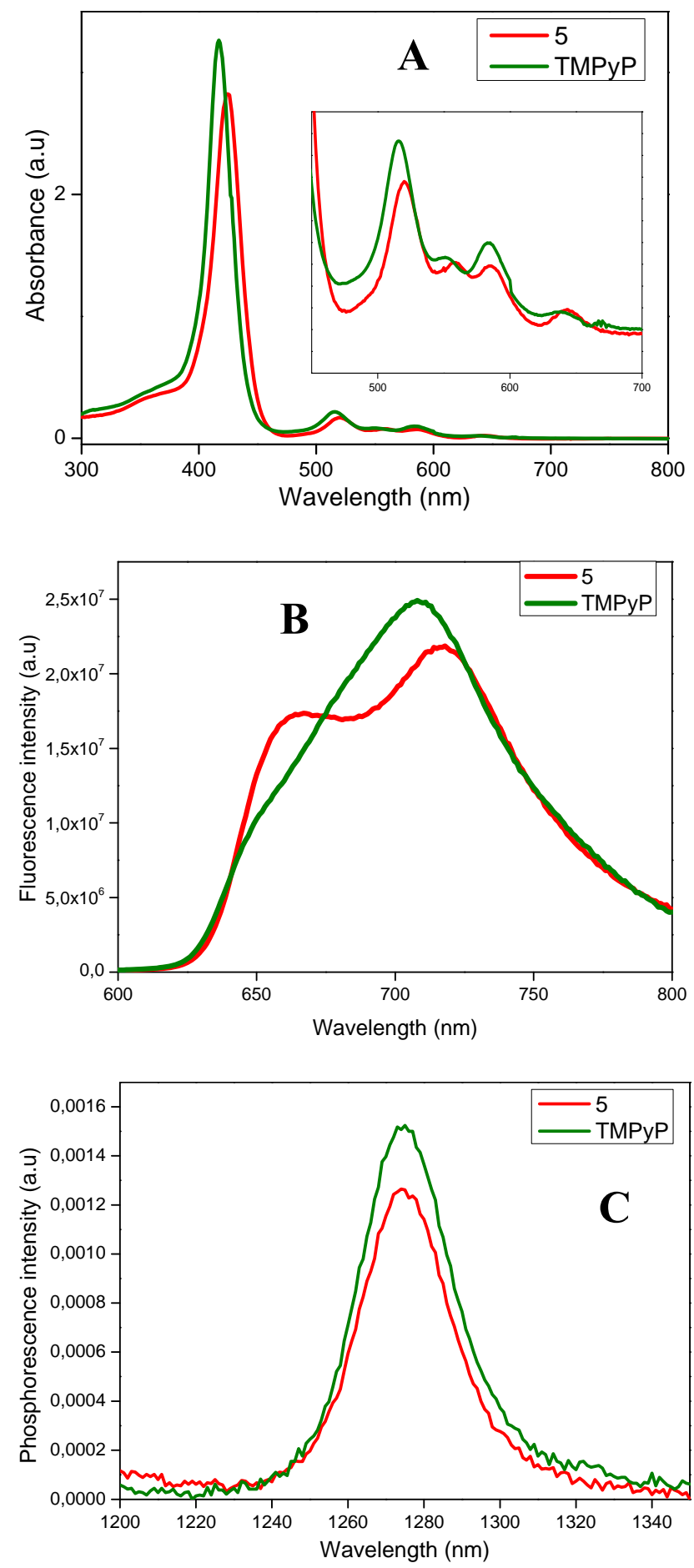

Figure 3. Absorption (A), fluorescence (B), and phosphorescence (C) spectra of 5 and TMPyP in $\mathrm{D}_{2} \mathrm{O}\left(\lambda_{\mathrm{exc}}=425 \mathrm{~nm}\right)$. 
Table 1. Fluorescence and phosphorescence properties of conjugate 5 and TMPyP in $\mathrm{D}_{2} \mathrm{O} .{ }^{\mathrm{a}} \mathrm{TPP}$ as standard $\left(\Phi_{\mathrm{F}}\right.$ (toluene $\left.)=0.11\right)^{49},{ }^{\mathrm{b}} \mathrm{TMPyP}$ as standard $\left(\Phi_{\Delta}\left(\mathrm{D}_{2} \mathrm{O}\right)=0.90\right)^{49}$, ${ }^{\text {c Literature value } ~}$ $67 \mu$ s in $\mathrm{D}_{2} \mathrm{O}^{51,52} \cdot\left(\lambda_{\mathrm{exc}}=425 \mathrm{~nm}\right)$

$\begin{array}{cccccc}\text { compd } & \lambda_{\mathbf{F} \max }(\mathbf{n m}) & \boldsymbol{\varphi}_{\mathbf{F}}{ }^{\mathrm{a}} & \boldsymbol{\varphi}_{\boldsymbol{\Delta}} & \boldsymbol{\tau}_{\mathbf{F}}(\mathbf{n s}) & \boldsymbol{\tau}_{\boldsymbol{\Delta}}(\boldsymbol{\mu s})^{\mathbf{c}} \\ \mathbf{5} & 717 & 0.067 & 0.789 & 5.2 & 65 \\ \mathbf{T M P y P} & 708 & 0.065 & 0.900^{\mathrm{b}} & 6.1 & 69\end{array}$

Bacterial photoinactivation. The photobactericidal activity of the final compound was established through biological assays against three bacterial strains (S. aureus, E. coli and P. aeruginosa, Table 2). $\mathbf{3}$ and TMPyP were chosen as PACT standards instead of $\mathbf{4}$ to avoid any interfering targeting of the maleimide function towards bacterial structures. In addition of these controls, commercial polymyxin B (PMBc) has been also tried out just to be compared with the modified peptide 1 .

The photobactericidal activity of the final compound $\mathbf{5}$ still had to be verified on Gram-positive strains. Even if cationic porphyrins, like TMPyP, are well-known for inactivating such strains after light irradiation, biological assays have to be tried out in order to inspect the consequences of the peptide coupling. Because of its Gram-negative specificity, commercial polymyxin B (PMBc) was ineffective against S. aureus. However, the derivative 1 prompted a noticeable decrease of the cell counts about $3 \log$ units at $50 \mu \mathrm{M}$ with or without light irradiation (data not shown), indicating that its $\mathrm{MBC}$ is higher than $50 \mu \mathrm{M}$. This bactericidal activity against $S$. aureus could be anticipated since the structure-activity relationship of polymyxin has revealed that reduction of number of cationic charges may provoke a decrease of efficiency against Gramnegative and an emerging activity against Gram-positive strains ${ }^{40}$. The conjugate $\mathbf{5}$ has shown a 
better efficacy ( $0.8 \mu \mathrm{M})$ against $S$. aureus than porphyrins alone $(5.0 \mu \mathrm{M})$ after light irradiation. The enhanced activity of $\mathbf{5}$ should not be considered due the bactericidal trend of $\mathbf{1}$ as the conjugate compound was found to be inactive in the dark (even at high concentration). Indeed, this enhancement is probably related to the amount of positive charges (leading also to a better solubility) due to the protonated amines of the polymyxin moiety in this range of $\mathrm{pH}$. Since cationic PSs are known for having a good interaction with some constituents of the cell wall of Gram-positive bacteria (such as the highly negatively charged teichoic acids), this unexpected enhancement of bactericidal activity might be due to a close proximity between compound 5 and these cells.

The subsequent biological assays were tried out against $P$. aeruginosa. Even if the bactericidal activity of PMBc and 1 was observed, the modification of the primary structure leads to a decrease of the efficiency. As expected, this slight decline of activity supported our strategy about the peptide modification. Despite the known insensitivity of this strain against PACT, the inefficiency of $\mathbf{3}$ after light irradiation may be explained by the quenching due to the primary amine, which leads to a decrease in singlet oxygen production compared to the production obtained with TMPyP. As the results obtained with conjugate $\mathbf{5}$ and peptide $\mathbf{1}$ are similar in the dark, the antimicrobial activity of the polymyxin moiety is preserved, despite the coupling with the porphyrin which, once more, brings supports to our synthesis pathway. Finally, this preserved efficacy in the dark and the enhanced activity of $\mathbf{5}$ after irradiation seems to support our initial purpose which was to target the membrane of Gram-negative bacteria in order to provide a stronger PACT effect. Moreover, the results obtained with $P$. aeruginosa were confirmed with E. coli, even if the determination of an accurate MBC could not been achieved with E. coli in contact with $\mathbf{5}$ in the dark. This issue may be explained by the result obtained 
after irradiation. Conjugate $\mathbf{5}$ has revealed a surprising efficacy after irradiation which appeared as good as against $S$. aureus. Since such efficiency against $E$. coli is not so frequent in PACT, an uncertainty remains about a potential activity induced by light pollution. Because of that, the common preparation of the assay, as well as the dilutions steps, may lead to a decrease in the bacterial concentration, then inducing fluctuations for the values in the dark. Anyhow, the large interval of $\mathrm{MBC}$ in the dark is still consistent with the remaining activity of the peptide which has been already demonstrated with the assays against $P$. aeruginosa.

Table 2. MBCs $(\mu \mathrm{M})$ against S. aureus, $\mathrm{P}$. aeruginosa and E. coli under two different conditions at $37{ }^{\circ} \mathrm{C} ; 20$ hours of white light irradiation $\left(4.83 \mathrm{~mW} / \mathrm{cm}^{2}\right)$ and in the dark. In these conditions, these concentrations inhibited at least $99.99 \%$ of bacteria (compared to the untreated control). The highest concentration tried out was $50 \mu \mathrm{M}$. “_“" corresponds to a lack of activity below this concentration.

\begin{tabular}{|c|c|c|c|c|c|c|}
\hline \multirow[b]{3}{*}{ Compounds } & \multicolumn{6}{|c|}{$M B C(\mu M)$} \\
\hline & \multicolumn{2}{|c|}{ S. aureus } & \multicolumn{2}{|c|}{ P. aeruginosa } & \multicolumn{2}{|c|}{ E. coli } \\
\hline & Light & Dark & Light & Dark & Light & Dark \\
\hline PMBc & - & - & 1.2 & 1.2 & 0.2 & 0.2 \\
\hline 1 & $>50$ & $>50$ & 10.0 & 10.0 & 5.0 & 5.0 \\
\hline 3 & 5.0 & - & - & - & 25.0 & - \\
\hline TMPуP & 5.0 & - & 20.0 & - & 18.0 & - \\
\hline 5 & 0.8 & - & 2.5 & 10.0 & 0.5 & $1.2-5.0$ \\
\hline
\end{tabular}

Bioanalytical experiments. Flow cytometry experiments were performed to compare the interaction of the final conjugate $\mathbf{5}$ and the cationic porphyrins alone with bacteria. In spite of the fluorescence quenching of $\mathbf{3}$ in usual solvents, this molecule was chosen for the comparison with 
compound 5. The previously seen photobactericidal activity of $\mathbf{3}$ suggests that the quenching effect may disappear in contact with bacteria, especially with S. aureus. Anyway, these analyses were also tried out using TMPyP (data not shown) and similar results were obtained, which is consistent with the literature ${ }^{35}$. Propidium iodide (PI) was added in order to keep track of the bacterial membrane permeability. To monitor the interaction strength between bacteria and PS, several washings were carried out after incubation with bacteria. Indeed, a persistent fluorescence after washings would highlight a strong interaction between bacteria and PS. Cytograms were divided in 4 different populations according to the fluorescence emitted by PI and PSs. The population Q1 refers to dead bacteria with permeable membrane (PI positive). The population Q2 refers to double positive bacteria (PI positive and PS positive). The population Q3 (PI and PS negative) refers to live bacteria, and the last population Q4 (PI negative and PS positive) to live bacteria labelled with PS. Based on three independent experiments, the average population repartition was calculated for each experimental condition.

The experiments showed that $S$. aureus is weakly labelled by $3(\mathrm{Q} 2+\mathrm{Q} 4=7.3 \%)$ (Figure 4) and this labelling decreased after washings. Otherwise, the incubation with conjugate $\mathbf{5}$ have led to a significant amount of labelled bacteria (Q2+Q4=37.6\%). Even if this fluorescence seemed to decrease after washing steps, numerous bacteria were still carrying the PS after 3 washings $(\mathrm{Q} 2+\mathrm{Q} 4=25.5 \%)$. Besides this remaining fluorescence, conjugate $\mathbf{5}$ did not seem to have any impact on the integrity of the bacterial membrane since the repartition of the dying population is consistent with the control $(\mathrm{Q} 1+\mathrm{Q} 2=16.3 \%)$. Thus, the results were congruent with the photobactericidal assays, since it appeared that $\mathbf{5}$ presented a stronger interaction with bacteria, and one can assume that ROS are produced very close to the bacterial cell. Retention of the bacterial viability and the decreasing in fluorescence following the washing steps may support 
our previous hypothesis according which the enhanced activity is due to the strong cationic character of compound $\mathbf{5}$.

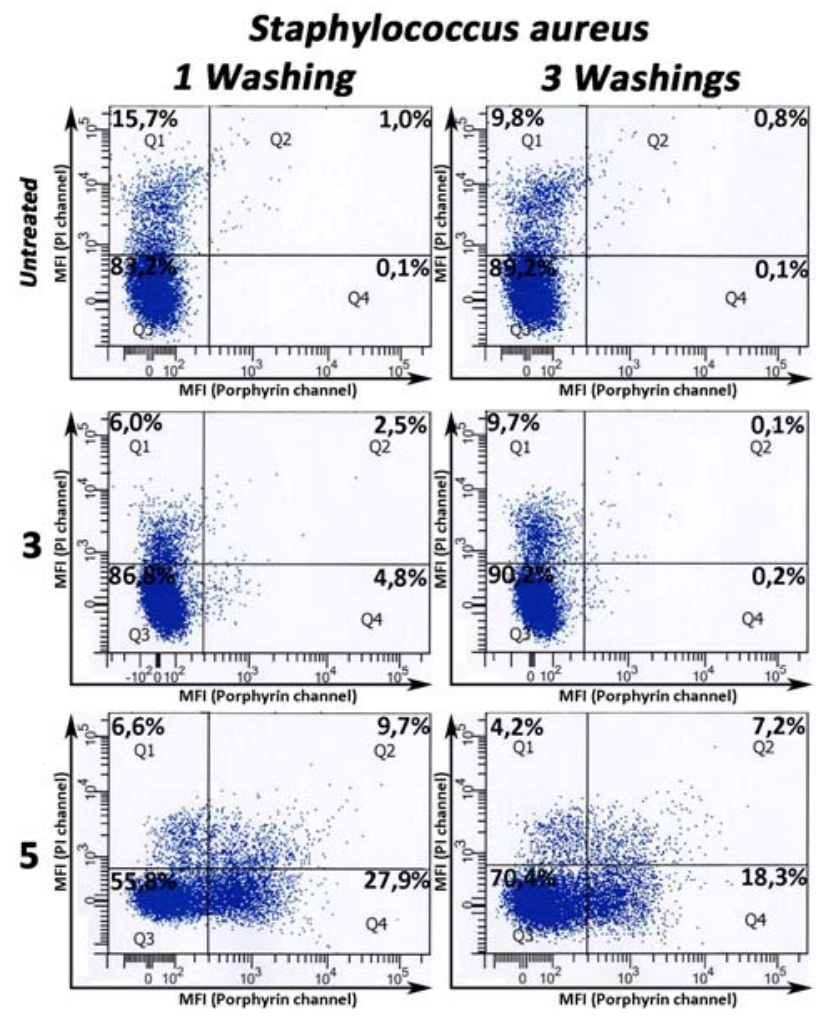

Figure 4. Flow cytometry analyses of $S$. aureus under different conditions: untreated, after incubation with $\mathbf{3}$, after contact with $\mathbf{5}$. Bacteria were suspended in a solution containing compounds 3 or $5(1 \mu \mathrm{M})$ for 30 minutes in $37^{\circ} \mathrm{C}$, then washed with saline. PI was added (10 $\mu \mathrm{L}, 0.5 \mathrm{mg} / \mathrm{mL}$ ) in order to detect and count the dead bacterial cells.

Experiments on Gram-negative strains deserved a careful consideration due to the use of the polymyxin derivative (Figure 5). Whereas 3 does not associate properly with E. coli as only remnant fluorescence is subsisting after the washing steps, 5 led to a major fluorescent population $(\mathrm{Q} 2+\mathrm{Q} 4=54.8 \%)$ which remained virtually identical even after 3 washing steps $(\mathrm{Q} 2+\mathrm{Q} 4=53.6 \%)$. This strong interaction between the PS and E. coli is consistent with the 
amount of bacteria which present a disturbed membrane. Indeed, whereas PI do not go through the membrane of untreated bacteria $(\mathrm{Q} 1=0.6 \%)$, the result obtained after an incubation with conjugate 5 led to a large amount of fluorescent and dying bacteria $(\mathrm{Q} 2=35.9 \%$ and $39.7 \%$, respectively). This difference between populations also confirmed the strong interaction between the conjugate and E. coli, since the membrane weakening may be considered as an account of the efficiency of the polymyxin moiety. Similar results were obtained with $P$. aeruginosa. In spite of a stronger penetration of PI (Q1 around 18\% for untreated bacteria), the same interaction of $\mathbf{5}$ with the bacterial cells was observed. Even if the MBC of conjugate $\mathbf{5}$ is higher for $P$. aeruginosa than for E. coli, the persistent bacterial membrane weakening and the strong interaction are more relevant against $P$. aeruginosa $(\mathrm{Q} 2=71.1 \%$ and $64.3 \%$, after one and three washings, respectively). Thus, according to the chosen synthesis pathway, the constancy of the polymyxin activity led to a significant bacterial PI fluorescence and the weakening of the membrane, through the interaction of the peptide moiety with lipid A. 

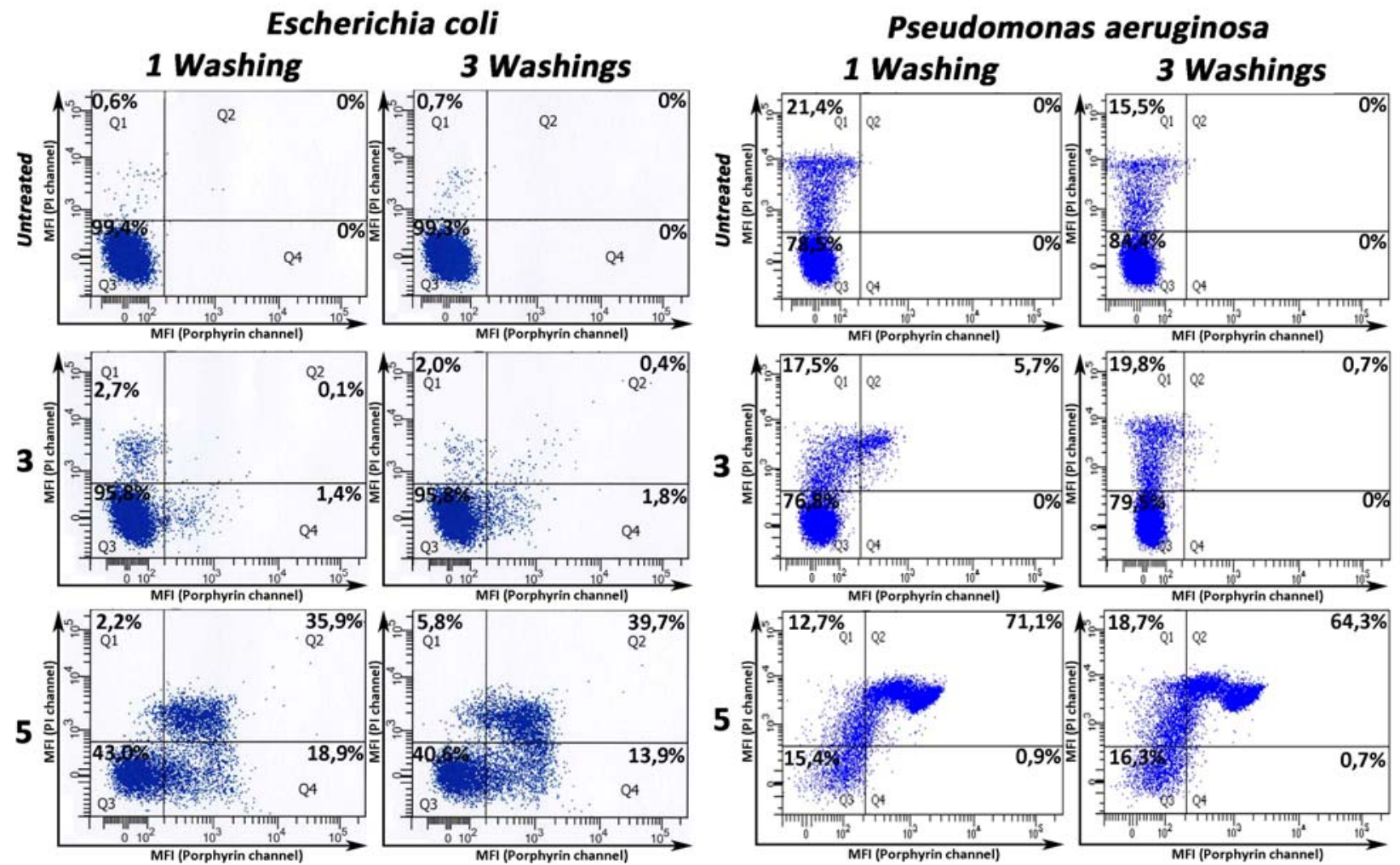

Figure 5. Flow cytometry analyses of $E$. coli and P. aeruginosa under different conditions: untreated, after incubation with $\mathbf{3}$ or $\mathbf{5}$. Bacteria were suspended in a solution of $\mathbf{3}$ or $\mathbf{5}(1 \mu \mathrm{M})$ for $30 \mathrm{mn}$ in $37{ }^{\circ} \mathrm{C}$, then washed with saline. PI was added $(10 \mu \mathrm{L}, 0.5 \mathrm{mg} / \mathrm{mL})$ in order to detect and count the dead bacterial cells.

Analyses by confocal microscopy were performed to visualize interactions between bacteria and the PSs (Figure 6). Whereas a remnant fluorescence was noticed after incubation with $\mathbf{3}$ (or TMPyP), the pictures obtained with 5 revealed a significant fluorescence of both strains. This strong fluorescence emitted from both strains is consistent with the flow cytometry results. In addition to its potential use in PACT, confocal imaging revealed that compound $\mathbf{5}$ could also be used as a Gram-negative probe for photodiagnostic. 

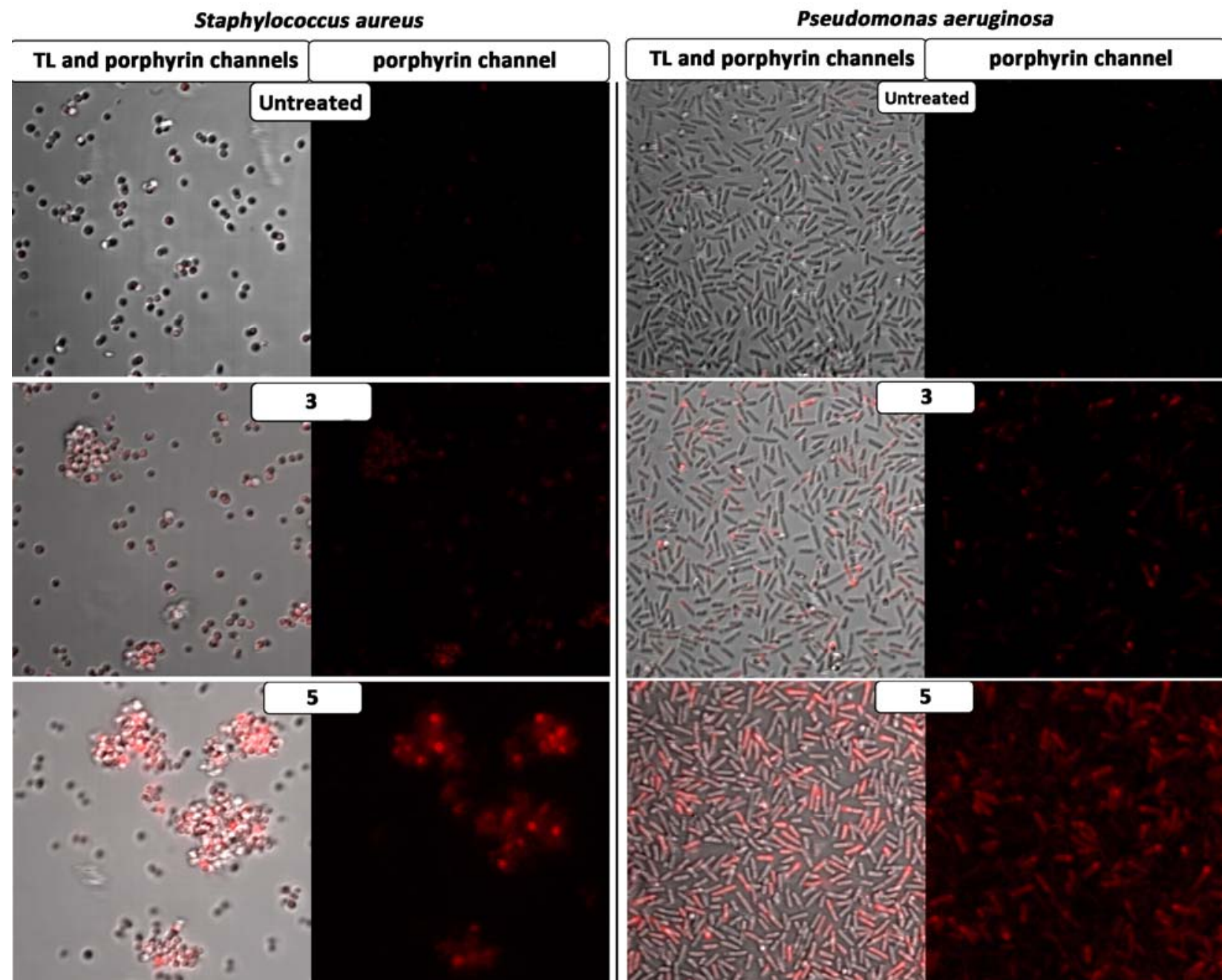

Figure 6. Confocal laser scanning microscopy imaging of $S$. aureus (left) and P. aeruginosa

(right) in different conditions: untreated, after incubation with $\mathbf{3}$ or $\mathbf{5}$. Bacteria were suspended in a solution of $\mathbf{3}$ or $\mathbf{5}(1 \mu \mathrm{M})$ for 30 minutes at $37^{\circ} \mathrm{C}$, then washed three times with saline.

Uptake studies with Fibroblasts. As fibroblasts play a key role during the wound healing process, uptake studies were performed on NHDF cells (normal human dermal fibroblasts). Confocal imaging was tried out in order to visualize the affinity of PSs for the NHDF cells. Firstly, photosensitizer solutions were incubated with NHDF alone. In comparison with untreated cells which have been used as standard for natural fluorescence, only residual fluorescence was observed (Figure S9). Thus, PSs 3, TMPyP and 5 seem not to present a strong 
interaction with these cells. Then, S. aureus or P. aeruginosa were mixed with NHDF (Figure 7). The use of conjugate $\mathbf{5}$ has led to the noticeable labelling of the different bacteria, whereas NHDF remained non-fluorescent and treatment with $\mathbf{3}$ revealed a complete lack of fluorescence. This promising result was obtained with the two bacterial strains in spite of the invasive capacity of $S$. aureus involving a close proximity with NHDF plasma membrane. Hence, conjugate $\mathbf{5}$ has also revealed encouraging results. Unfortunately, conjugate 5 sticks strongly to polystyrene. Since the walls of the 96 well-plates could not be efficiently washed, usual protocols (as MTT protocol) could not be used to measure the cytotoxicity of the compound. Thus, further biological studies using epidermal in vitro models (from Episkin ${ }^{\circledR}$ for example) will be applied. Anyway, the microcopy imaging has shown the selective affinity of the conjugate for both bacterial strains. As a close proximity with these compounds is necessary to induce the PACT effect, such interaction would involve the photoinactivation of the bacteria right before any unwanted effect towards mammalian cells 
NHDF cells with Staphylococcus aureus

NHDF cells with Pseudomonas aeruginosa
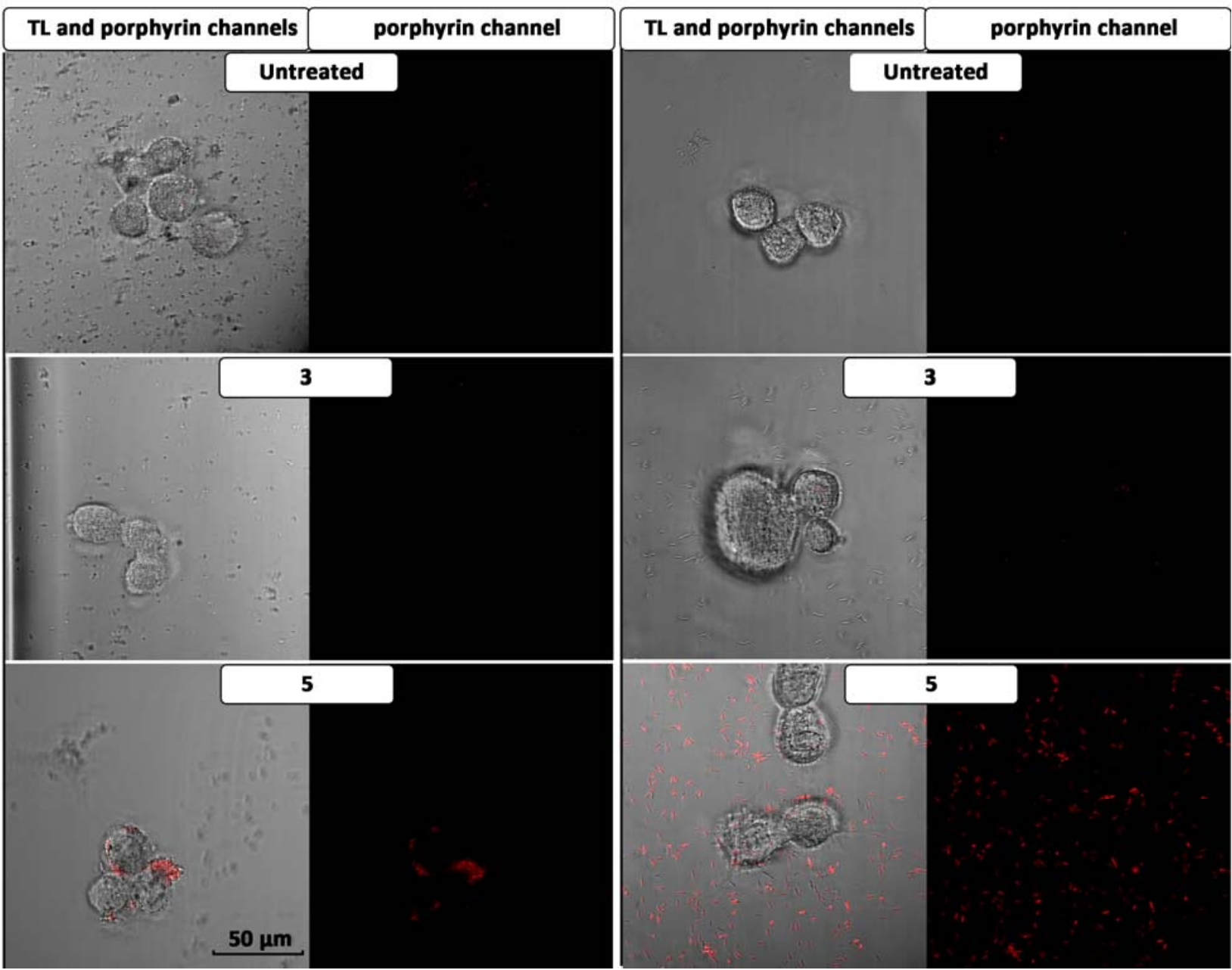

Figure 7. Confocal laser scanning microscopy imaging of NHDF and bacteria in different conditions: untreated, after incubation with $\mathbf{3}$ or $\mathbf{5}$. Cells were suspended in a solution of $\mathbf{3}$ or $\mathbf{5}$ (1 $\mu \mathrm{M}$ ) for $30 \mathrm{~min}$ at $37^{\circ} \mathrm{C}$, then washed 3 times with PBS.

\section{CONCLUSION.}

In order to improve PACT, previous studies have highlighted a promising strategy based on the addition of antimicrobial peptides to different PSs. In this work, the conjugation of a cationic porphyrin to a polymyxin derivative leads to a significant photobactericidal efficiency. As the synthesis pathway was based on the structure-activity relationship of the peptide, the weakening 
of the outer-membrane of Gram-negative strains was conserved. Because of the remaining activity of the polymyxin moiety, this conjugate has attested a strong interaction with bacteria including, surprisingly, a Gram-positive strain. Compound $\mathbf{5}$ has shown a promising selective affinity for bacteria, contrary to fibroblasts. Even if the activity of the polymyxin moiety may involve the apparition of superbugs (in particular in absence of light), photosensitizing conjugates offer less risk than the peptide by itself as the PACT effect has the ability to photoinactivate such strains. Thus, the use of such conjugate compounds, instead of the peptide alone, may present many advantages such as limiting the apparition of resistant strains.

\section{EXPERIMENTAL SECTION.}

General Methods. All organic materials and microbial nutriments were purchased from commercial suppliers (Acros Organics, Alfa Aesar, Grosseron, Sigma-Aldrich, TCI). All amino acids and the 2-chlorotrityl resin were obtained from Iris Biotech $\mathrm{GmbH}$ (Marktredwitz, Germany). Commercial Polymyxin B sulfate (PMBc) was provided by TCI. Solvents used for the UV-Vis and fluorescence measurements were of spectroscopic grade and were stored in a dark place. Column chromatography was carried out with silica gel (60 ACC, 15- $40 \mu \mathrm{m}$, Merck). 5-10,15,20-tetrakis(4- $N$-methylpyridyl)-21H,23H-porphyrin (TMPyP) was provided by PorphyChem (Dijon, France). Reverse phase chromatography was performed on RediSep®Rf C18 column (43g), mounted on an Interchim ${ }^{\circledR}$ puriFlash $^{\mathrm{TM}} 430$ apparatus, with acetonitrile (HPLC grade $+0.1 \%$ TFA) and distilled water $(+0.1 \%$ TFA $)$ as eluents. Continuous monitoring of effluent absorbance allowed the detection of the peptide $(\lambda=214 \mathrm{~nm})$ or the porphyrinpolymyxin conjugate $(\lambda=418 \mathrm{~nm}) .{ }^{1} \mathrm{H}$ and ${ }^{13} \mathrm{C}$ nuclear magnetic resonance $\left({ }^{1} \mathrm{H}-\mathrm{NMR}\right.$ and ${ }^{13} \mathrm{C}$ NMR) spectra were recorded in deuterated solvents, with Bruker DPX 400 and 500 spectrometers. Chemical shifts are reported as $\delta$ (parts per million), downfield from internal 
TMS. Multiplicities are reported as follows: $\mathrm{s}=$ singlet, $\mathrm{d}=$ doublet, $\mathrm{m}=$ multiplet. Electron spray ionization mass spectra (ESI-MS) were recorded on a Sciex 4000 Q-TRAP®, monitored by Sciex Analyst 1.6.2. For all peptidic compounds, high resolution electrospray ionization mass spectra (HR ESI-MS) were performed on a Bruker maXis mass spectrometer by the ICOA/CBM (FR2708) platform (Orléans - France).

Chemical Synthesis. Synthesis of the PMB derivative "PMB-SH" (1). The synthesis of polymyxins has already been described by $\mathrm{Xu}$ and co-workers ${ }^{38}$. The protocol was modified by replacing the last Fmoc-Dab(Boc)-OH by Fmoc-Cys(Mmt)-OH during the sequential coupling. An improvement has been brought to the Dde group removal. Hydroxylamine hydrochloride $(1.25 \mathrm{~g}, 18.0 \mathrm{mmol})$ and imidazole $(0.918 \mathrm{~g}, 13.5 \mathrm{mmol})$ were dissolved into $N$-methyl-2pyrrolidone $(5 \mathrm{~mL})$. Addition of DCM $(1 \mathrm{~mL})$ to this solution resulted in Dde removal from the suspended peptide after 3 hours at room temperature. After the final cleavage with TFA/ $\mathrm{H}_{2} \mathrm{O} / \mathrm{TIPS}(95 / 2.5 / 2.5, \mathrm{v} / \mathrm{v} / \mathrm{v})$, the crude mixture was directly freeze-dried, and then purified by reverse phase chromatography. Compound $\mathbf{1}$ was obtained as a white powder, following freeze-drying of the peptide-containing fractions. MS (ESI positive mode) $\left[\mathrm{C}_{54} \mathrm{H}_{93} \mathrm{~N}_{15} \mathrm{O}_{13} \mathrm{~S}\right]$ : calculated $[\mathrm{M}+2 \mathrm{H}]^{2+}$ 596.84, found 596.66 .

Synthesis of 5-(4-acetamidophenyl)-10,15,20-tri(4-pyridyl)porphyrin (2). Freshly distilled pyrrole $(6.66 \mathrm{~mL}, 96.0 \mathrm{mmol}, 4 \mathrm{eq})$ was added dropwise to a refluxed solution $\left(140{ }^{\circ} \mathrm{C}\right)$ of 4 pyridylcarboxaldehyde $(6.79 \mathrm{~mL}, 72.0 \mathrm{mmol}, 3 \mathrm{eq})$ and 4-acetamidobenzaldehyde $(3.923 \mathrm{~g}, 24.0$ mmol, $1 \mathrm{eq})$ dissolved in propionic acid $(100 \mathrm{~mL})$. The mixture was stirred under reflux for 3 hours. After removal of propionic acid in vacuo, the crude solid was dissolved in $\mathrm{CHCl}_{3}$ filtered through a small pad of silica gel and washed with $\mathrm{CHCl}_{3} / \mathrm{EtOH}(90 / 10$, v/v). After removal of 
the solvent under vacuum, porphyrins were purified by silica gel column chromatography $\left(\mathrm{CHCl}_{3} / \mathrm{EtOH}(98 / 2, \mathrm{v} / \mathrm{v})\right.$ and compound 2 was obtained as a light purple powder with $2 \%$ yield. TLC $\left(\mathrm{CHCl}_{3} / \mathrm{EtOH} 90 / 10, \mathrm{v} / \mathrm{v}\right): \mathrm{R}_{\mathrm{f}}=0.54$. UV-visible $(\mathrm{MeOH}), \lambda_{\max }(\mathrm{nm})\left(\varepsilon \log \mathrm{L} \cdot \mathrm{mol}^{-1} \cdot \mathrm{cm}^{-1}\right):$ 415 (5.33), 512 (3.95), 547 (3.52), 588 (3.44), 644 (3.13). ${ }^{1} \mathrm{H}$ NMR (500 MHz, $\left.\mathrm{CDCl}_{3}\right): \delta=9.04$ (m, 6H, Ho-py), 8.80 (m, 8H, H $\beta$-pyrrolic), 8.17 (d, J = 8.0 Hz, 2H, Ho-pheacetamido), 8.15 (m, 6H,

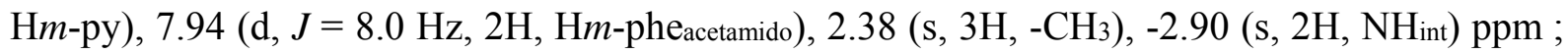
MS (ESI+) $\left[\mathrm{C}_{40} \mathrm{H}_{26} \mathrm{~N}_{8}\right]$ : calculated $[\mathrm{M}+3 \mathrm{H}]^{3+} 225.75$, found 225.83 .

Synthesis of 5-(4-aminophenyl)-10,15,20-tri(4-N-methylpyridinium)porphyrin triiodide (3). An excess of iodomethane $(0.83 \mathrm{~mL}, 13.3 \mathrm{mmol}, 45 \mathrm{eq})$ was added to a solution of 2 (200 $\mathrm{mg}, 0.30$ mmol, 1 eq) in anhydrous DMF $(50 \mathrm{~mL})$ under argon atmosphere. The mixture was stirred for 3 hours at $140{ }^{\circ} \mathrm{C}$. DMF and excess iodomethane were removed with a rotary vane pump under heating $\left(70{ }^{\circ} \mathrm{C}\right)$ to obtain the $N$-methylporphyrin derivative in quantitative yield as a light purple-brown powder without further purification. Then, the powder was dissolved in a solution of $\mathrm{H}_{2} \mathrm{O} / \mathrm{TFA}(75 / 25, \mathrm{v} / \mathrm{v})$ and stirred under reflux for 5 hours. The aqueous solution was removed and compound $\mathbf{3}$ was freeze-dried to obtain a purple-brown powder with a quantitative yield. UV-visible (MeOH), $\lambda \max (\mathrm{nm})\left(\varepsilon \log \mathrm{L} \cdot \mathrm{mol}^{-1} \cdot \mathrm{cm}^{-1}\right): 428(5.05), 521$ (4.05), 564 (3.88), 593 (3.84), 656 (3.47). ${ }^{1} \mathrm{H}$ NMR (500 MHz, DMSOd6) $: \delta(\mathrm{ppm})=9.49(\mathrm{~d}, J=6.5 \mathrm{~Hz}, 6 \mathrm{H}, \mathrm{Ho}-\mathrm{py})$, $9.11-8.80$ (m, 8H, Hpyrr), 9.00 (d, $J=6.5 \mathrm{~Hz}, 6 \mathrm{H}, \mathrm{Hm}$-py), 7.94 (d, $J=8.5 \mathrm{~Hz}, 2 \mathrm{H}$, Ho-phe), 7.15 (d, $J=8.5 \mathrm{~Hz}, 2 \mathrm{H}, \mathrm{Hm}-\mathrm{phe}), 4.73\left(\mathrm{~s}, 9 \mathrm{H}, \mathrm{N}^{+}-\mathrm{CH}_{3}\right),-2.96$ (s, 2H, NHint) ppm ; MS (ESI+) $\left[\mathrm{C}_{44} \mathrm{H}_{37} \mathrm{I}_{3} \mathrm{~N}_{8}\right]$ : calculated $[\mathrm{M}]^{3+} 225.77$, found 225.74 .

Synthesis of 5-(4-(maleimidohexanoamidophenyl)-10,15,20-tri(4- N-methylpyridinium)porphyrin triiodide (4). A solution of 3 (373.3 mg, $0.353 \mathrm{mmol}, 1 \mathrm{eq}), 6$-maleimidohexanoic acid (223.7 mg, $1.059 \mathrm{mmol}, 3 \mathrm{eq})$, HCTU (404.3 mg, $0.977 \mathrm{mmol}, 2.8 \mathrm{eq})$ and DIEA (0.150 mL, 0.880 
mmol, 2.5 eq) dissolved in DMF (45 mL) was gently stirred overnight at room temperature. After evaporation of the solvent, the crude was directly purified by reverse phase chromatography. Compound $\mathbf{4}$ was recovered as a brown powder after freeze-drying, with a yield around 30\% (132.5 mg, $0.106 \mathrm{mmol}) . \mathrm{UV}$-visible $(\mathrm{MeOH}), \lambda_{\max }(\mathrm{nm})\left(\varepsilon \log \mathrm{L} \cdot \mathrm{mol}^{-1} . \mathrm{cm}^{-1}\right)$ : 428 (5.26), 519 (4.06), 556 (3.78), 593 (3.65), 650 (3.28). ${ }^{1} \mathrm{H}$ NMR (500 MHz, DMSOd6) : $\delta=$ 10.42 (s, 1H, NHamide), 9.49 (d, $J=6.5 \mathrm{~Hz}, \mathrm{Ho}-\mathrm{py}), 9.10$ (m, 8H, Hpyr), 9.00 (d, $J=6.5 \mathrm{~Hz}, 6 \mathrm{H}$, Hm-py), 8.15 (d, $J=8.4 \mathrm{~Hz}, 2 \mathrm{H}, \mathrm{Ho}-\mathrm{phe}), 8.11$ (d, $J=8.4 \mathrm{~Hz}, 2 \mathrm{H}, \mathrm{Hm}$-phe), 7.05 (s, 2H,

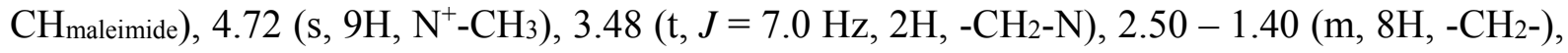
$-2.97(\mathrm{~s}, 2 \mathrm{H}, \mathrm{NH}) \mathrm{ppm} ; \mathrm{MS}(\mathrm{ESI}+)\left[\mathrm{C}_{54} \mathrm{H}_{48} \mathrm{I}_{3} \mathrm{~N}_{9} \mathrm{O}_{3}\right]$ : calculated $[\mathrm{M}+\mathrm{H}]^{3+} 290.46$, found 290.53 .

Synthesis of the final conjugate porphyrin-PMB (5). 4 (41.6 mg, $33.2 \mu \mathrm{mol}, 1 \mathrm{eq})$ and 1 (39.6 $\mathrm{mg}, 33.2 \mu \mathrm{mol}, 1 \mathrm{eq})$ were dissolved in a phosphate buffer solution $(0.5 \mathrm{M})$ at $\mathrm{pH}$ 6.5. The mixture was gently stirred overnight at room temperature. The crude was directly purified by reverse phase chromatography. Final product $\mathbf{5}$ was obtained as a freeze-dried brown powder with $72 \%$ yield $(58.3 \mathrm{mg}, 23.8 \mu \mathrm{mol})$. UV-visible $(\mathrm{MeOH}), \lambda \max (\mathrm{nm})\left(\varepsilon \log \mathrm{L} \cdot \mathrm{mol}^{-1} . \mathrm{cm}^{-1}\right): 427$ (5.33), 519 (4.24), 556 (3.95), 594 (3.83), 650 (3.45). HRMS (ESI+) $\left[\mathrm{C}_{108} \mathrm{H}_{141} \mathrm{I}_{3} \mathrm{~N}_{24} \mathrm{O}_{16} \mathrm{~S}\right]$ : $[\mathrm{M}]^{3+}$ calculated 687.3554 , found 687.3569 .

Spectroscopic Measurements. Absorption spectra were recorded on a UV-3600 UV-visible double beam spectrophotometer (Shimadzu, Marne La Vallée, France). Fluorescence spectra were recorded on a Fluorolog FL3-222 spectrofluorometer (Horiba Jobin Yvon, Longjumeau, France) equipped with a $450 \mathrm{~W}$ Xenon lamp, a thermostated cell compartment $\left(25^{\circ} \mathrm{C}\right)$, a UVvisible R928 photomultiplier (Hamamatsu Japon) and an InGaAs infrared detector (DSS16A020L Electro-Optical System Inc, Phoenixville, PA, USA). Excitation beam was diffracted by a double ruled grating SPEX monochromator (1200 grooves/mm blazed at $330 \mathrm{~nm}$ ). Emission 
beam was diffracted by a double ruled grating SPEX monochromator (1200 grooves/mm blazed at $500 \mathrm{~nm}$ ). Singlet oxygen emission was detected through a double ruled grating SPEX monochromator (600 grooves $/ \mathrm{mm}$ blazed at $1 \mu \mathrm{m})$ and a long-wave pass $(780 \mathrm{~nm})$. All spectra were recorded from solutions introduced in four-face quartz cuvettes. All the emission spectra (fluorescence and singlet oxygen luminescence) have been displayed with the same absorbance (less than 0.2) with lamp and photomultiplier correction. Fluorescence quantum yields $\left(\Phi_{\mathrm{F}}\right)$ were determined using a tetraphenyl porphyrin (TPP) solution in toluene as the fluorescence standard $\left(\Phi_{\mathrm{F}}=0.11\right)$. Quantum yield of ${ }^{1} \mathrm{O}_{2}$ production was determined by direct analysis of the ${ }^{1} \mathrm{O}_{2}$ near-infrared luminescence at $1270 \mathrm{~nm}$. Tetra( $N$-methylpyridyl)porphyrin (TMPyP) was chosen as the reference solution due to its high ${ }^{1} \mathrm{O}_{2}$ quantum yield in $\mathrm{D}_{2} \mathrm{O}\left(\Phi_{\Delta}=0.90\right)$. Timeresolved experiments were performed using for excitation a pulsed laser diode emitting at 407 nm (LDH-P-C-400M, FWHM $<70$ ps, 1 MHz) coupled with a PDL 800-D driver (both from PicoQuant GmbH, Berlin, Germany) and for detection an avalanche photodiode SPCM-AQR-15 (EG \& G, Vaudreuil, Canada) coupled with a $550 \mathrm{~nm}$ long-wave pass filter as detection system. Acquisition was performed by a PicoHarp 300 module with a PHR-800 4 channel router (both PicoQuant GmbH, Berlin, Germany). Fluorescence decays were recorded using the single photon counting method. Data were collected up to 1000 counts accumulated in the maximum channel and analyzed using Time Correlated Single Photon Counting (TCSPC) software (PicoQuant GmbH, Berlin, Germany) based on iterative reconvolution using a LevensbergMarquandt algorithm, enabling the obtention of multi-exponential profiles (mainly one or two exponentials in our cases). Singlet oxygen lifetime measurements have been performed on a TEMPRO-01 spectrophotometer (Horiba Jobin Yvon, Longjumeau, France) composed of a SpectraLED-415 pulsed diode excitation source emitting at $415 \mathrm{~nm}$, a cell compartment, a Seya- 
Namioka type emission monochromator $(600-2000 \mathrm{~nm})$ and a H10330-45 near-infrared photomultiplier tube with thermoelectric cooler (Hamamatsu, Japan) as detection system. The system was monitored by a FluoroHub-B single photon counting controller and the DataStation and DAS6 softwares (Horiba Jobin Yvon). Emission spectra have been performed on a Fluorolog FL3-22 spectrofluorometer (Horiba Jobin Yvon, Longjumeau, France) equipped with a $450 \mathrm{~W}$ Xenon lamp, a xenon flash lamp, a thermostated cell compartment $\left(25^{\circ} \mathrm{C}\right)$ and a $\mathrm{R} 928$ UV-visible photomultiplier (Hamamatsu Japan). The system was monitored by a FluoroHub-B single photon counting controller. The FluorEssence software (Horiba Jobin Yvon) was used for recording the emission spectra; the DataStation and DAS6 softwares (Horiba Jobin Yvon) were used for phosphorescence lifetime measurements.

Bacterial Cultures. Gram-positive (S. aureus CIP76.25) and Gram-negative ( $P$. aeruginosa CIP76110 and E. coli CIP54.8T) bacterial strains were obtained from Institut Pasteur (Paris, France). These strains were cultured in liquid tryptic soy (pancreatic casein extract $17 \mathrm{~g} / \mathrm{L}$, soy flour papaic digest $3 \mathrm{~g} / \mathrm{L}$, dextrose $2.5 \mathrm{~g} / \mathrm{L}, \mathrm{NaCl} 5 \mathrm{~g} / \mathrm{L}$, and $\mathrm{K}_{2} \mathrm{HPO}_{4} 2.5 \mathrm{~g} / \mathrm{L}$ ) and incubated overnight at $37{ }^{\circ} \mathrm{C}$ under aerobic conditions. Square plates were kept warm inside a SR1000 Thermosi incubator. Antimicrobial experiments used a Heidolph Unkubator 1000 equipped with an Unimax 1010 orbital platform shaker. An Isotech Lightmeter 1335 light meter was used to measure the effective irradiation power.

Bacteria Photoinactivation. Fresh solutions of porphyrin 3 and TMPyP in DMSO were mixed with tryptic soy culture medium. DMSO concentration never exceeded 1\% (v/v). Furthermore, 1, 5 and PMBc were directly dissolved into the culture media. From these mixtures, $1 \mathrm{~mL}$ of serial dilutions (50 $\mu \mathrm{M}$ down to $78 \mathrm{nM}$ ) were transferred into two 24-well plates (BD Falcon). $1 \mathrm{~mL}$ of a culture at a concentration of $2.10^{5} \mathrm{UFC} / \mathrm{ml}$ was deposited in each well. The 24 -well plates 
were irradiated with LED visible light. The fluence rate $\left(4.83 \mathrm{~mW} / \mathrm{cm}^{2}\right)$ was measured with a light meter. Plates were incubated under gentle shaking $(200 \mathrm{rpm})$ at $37^{\circ} \mathrm{C}$ for 20 hours (totaling $348 \mathrm{~J} / \mathrm{cm}^{2}$ fluence). Controls consisting of 24 -well plates were prepared in the same conditions but kept in the dark. Six independent experiments were performed with each strain. Bacterial count was performed after a 10 fold serial dilution of each well. Each dilution was spread on tryptic soy agar plates using an automatic plater (easySPIRAL ${ }^{\circledR}$, Interscience). After incubation at $37{ }^{\circ} \mathrm{C}$ for 24 hours, colonies were counted to determine total $\mathrm{CFU}$ per $\mathrm{mL}(\mathrm{CFU} / \mathrm{mL})$. The minimum bactericidal concentration (MBC) corresponds to the concentration of the active compound for which $99.99 \%$ of the bacteria have been killed (i.e. $4 \log$ reduction compared to the untreated control).

Flow cytometry. For each bacterial strain, $10^{8} \mathrm{CFU}$ were put in contact with $1 \mathrm{~mL}$ of each PS (1 $\mu \mathrm{M}$ in PBS) for $30 \mathrm{~min}$ at $37{ }^{\circ} \mathrm{C}$ in the dark. Then, bacteria were retrieved by centrifugation at $10,000 \mathrm{rpm}$ for $3 \mathrm{~min}$, and washed with sterile saline. Bacteria were resuspended in $500 \mu 1 \mathrm{X}$ PBS, after one or three successive washing steps. Before analysis by flow cytometry, $10 \mu \mathrm{L}$ of propidium iodide (PI, $0.5 \mathrm{mg} / \mathrm{mL}$ ) were added to the bacterial suspension. Fluorescences were analyzed with a BD FACSAria ${ }^{\mathrm{TM}}$ III cell sorter (BD Biosciences, France). Bacterial cells were excited by two lasers. PS were excited with a $407 \mathrm{~nm}$ violet laser and the fluorescence emitted was detected with a BV711 (710/50 nm) filter. PI was excited with a $561 \mathrm{~nm}$ yellow-green laser and the fluorescence emitted was detected with a BV605 (610/20nm) filter. For S. aureus and E. coli, 10000 events were counted, whereas 50000 events were counted for P. aeruginosa.

Confocal miscroscopy. For confocal microscopy analysis, the different bacterial suspensions were transferred into $\mathrm{NUNC}^{\mathrm{TM}}$ Lab-Tek $^{\mathrm{TM}}$ II chamber coverglass (Corning, France). A UV diode $(405 \mathrm{~nm})$ was used to excite the PS. Emitted fluorescence was monitored between $595 \mathrm{~nm}$ 
and $750 \mathrm{~nm}$. Fluorescence was analyzed with a LSM880 laser scanning confocal microscope (Zeiss, Germany). Image acquisition and analysis were realized with a Zeiss ZEN Lite software.. Images were obtained with a 100X objective lens.

Fibroblasts. The human normal fibroblast cell line NHDF (normal human dermal fibroblasts), derived from human normal derma (Lonza) was cultured in Fibroblast Basal Medium (FBM) supplemented with Fibroblast Growth Medium-2 (FGM-2) Bullet kit (Lonza), containing 2\% fetal bovine serum (FBS), $0.1 \%$ insulin, $0.1 \%$ gentamicin, amphotericin GA 1000, 0.1\% fibroblast growth factor (FGF). NHDF cells were cultured at $37{ }^{\circ} \mathrm{C}$ in $95 \%$ humidified air in the presence of $5 \% \mathrm{CO}_{2}$

Bacterial imaging over NHDF cells. NHDF cells (5 000 cells) were seeded in a 8-well Lab$\mathrm{Tek}^{\mathrm{TM}} \mathrm{II}$ chamber coverglass (NUNC) in complete FBM culture medium for 48 hours at $37^{\circ} \mathrm{C}$. $10^{7} \mathrm{CFU}$ were prepared and washed three times with PBS. $5.10^{6} \mathrm{CFU}$ were directly added to each well. After $30 \mathrm{~min}$ of incubation at $37^{\circ} \mathrm{C}$, the supernatant was removed and the wells were washed once with PBS. Then, $500 \mu \mathrm{L}$ of PS solutions ( $1 \mu \mathrm{M}$ in PBS) were deposited after 30 min at $37{ }^{\circ} \mathrm{C}$ in the dark, three washing steps were done, and then confocal microscopy imaging was carried out as described before, with a 40X objective lens.

\section{ASSOCIATED CONTENT}

Supporting information. Synthetic route to 1, NMR and MS analyses of all compounds, absorbance spectra in $\mathrm{MeOH}$ for all compounds, additional confocal microscopy imaging (NHDF alone or with bacteria).

\section{AUTHOR INFORMATIONS}




\section{Corresponding Authors}

*Tan Sothea Ouk, phone +33(0)-5-5545-4402: E-mail : tan-sothea.ouk@unilim.fr

*Vincent Sol, phone: +33(0)-5-5545-7490; fax: +33(0)-5-5545-7202 E-mail : vincent.sol@,unilim.fr

\section{ACKNOWLEDGMENTS}

We thank the 'Conseil Régional du Limousin' for financial support. The authors are indebted to Dr. Michel Guilloton for help in manuscript editing, and Claire Carrion (BISCEm - Limoges University) for confocal microscopy imaging.

\section{ABBREVIATIONS USED}

LPS, lipopolysaccharide; LTA, lipoteichoic acid; MDR, multi-drug resistant; MBC, minimal bactericidal concentration; NHDF, normal human dermal fibroblast; ROS, reactive oxygen species; PACT, photodynamic antimicrobial chemotherapy; PBS, phosphate-buffered saline; PI, propidium iodide; PMBc, polymyxin B commercial; PS, photosensitizer; TMPyP, mesotetrakis( $N$-methylpyridinium)porphyrin; TPP, meso-tetrakis(phenyl)porphyrin.

\section{REFERENCES}

(1) Bolognia, J. L.; Jorizzo, J. L.; Schaffer, J. V. Dermatology: 2-Volume Set, 3rd Edition, United States of America.; Saunders Elsevier, 2012.

(2) James, G. A.; Swogger, E.; Wolcott, R.; Pulcini, E. deLancey; Secor, P.; Sestrich, J.; Costerton, J. W.; Stewart, P. S. Wound Repair Regen. 2008, 16 (1), 37-44.

(3) Bjarnsholt, T. APMIS 2013, 121, 1-58.

(4) Bowler, P. G.; Duerden, B. I.; Armstrong, D. G. Clin. Microbiol. Rev. 2001, 14 (2), 244 269.

(5) Edwards-Jones, V.; Greenwood, J. E. Burns 2003, 29 (1), 15-24.

(6) Davies, C. E.; Hill, K. E.; Wilson, M. J.; Stephens, P.; Hill, C. M.; Harding, K. G.; Thomas, D. W. J. Clin. Microbiol. 2004, 42 (8), 3549-3557.

(7) Mihu, M. R.; Martinez, L. R. Virulence 2011, 2 (2), 97-102.

(8) Mottola, C.; Mendes, J. J.; Cristino, J. M.; Cavaco-Silva, P.; Tavares, L.; Oliveira, M. Folia Microbiol. (Praha) 2016, 61 (1), 35-43. 
(9) Vatansever, F.; de Melo, W. C. M. A.; Avci, P.; Vecchio, D.; Sadasivam, M.; Gupta, A.; Chandran, R.; Karimi, M.; Parizotto, N. A.; Yin, R.; Tegos, G. P.; Hamblin, M. R. FEMS Microbiol. Rev. 2013, 37 (6), 955-989.

(10) Tavares, A.; Carvalho, C. M. B.; Faustino, M. A.; Neves, M. G. P. M. S.; Tomé, J. P. C.; Tomé, A. C.; Cavaleiro, J. A. S.; Cunha, Â.; Gomes, N. C. M.; Alves, E.; Almeida, A. Mar. Drugs 2010, 8 (1), 91-105.

(11) Dysart, J. S.; Patterson, M. S. Phys. Med. Biol. 2005, 50 (11), 2597-2616.

(12) Fu, X.; Fang, Y.; Yao, M. BioMed Res. Int. 2013.

(13) Henderson, B. W.; Dougherty, T. J. Photochem. Photobiol. 1992, 55 (1), 145-157.

(14) Detty, M. R.; Gibson, S. L.; Wagner, S. J. J. Med. Chem. 2004, 47 (16), 3897-3915.

(15) Dougherty, T. J.; Gomer, C. J.; Henderson, B. W.; Jori, G.; Kessel, D.; Korbelik, M.; Moan, J.; Peng, Q. J. Natl. Cancer Inst. 1998, 90 (12), 889-905.

(16) Minnock, A.; Vernon, D. I.; Schofield, J.; Griffiths, J.; Parish, J. H.; Brown, S. B. Antimicrob. Agents Chemother. 2000, 44 (3), 522-527.

(17) Reddi, E.; Ceccon, M.; Valduga, G.; Jori, G.; Bommer, J. C.; Elisei, F.; Latterini, L.; Mazzucato, U. Photochem. Photobiol. 2002, 75 (5), 462-470.

(18) Alves, E.; Costa, L.; Carvalho, C. M. B.; Tomé, J. P. C.; Faustino, M. A.; Neves, M. G. P. M. S.; Tomé, A. C.; Cavaleiro, J. A. S.; Cunha, Â.; Almeida, A. BMC Microbiol. 2009, 9, 70.

(19) Hamblin, M. R.; Dai, T. Photodiagnosis Photodyn. Ther. 2010, 7 (2), 134.

(20) Saino, E.; Sbarra, M. S.; Arciola, C. R.; Scavone, M.; Bloise, N.; Nikolov, P.; Ricchelli, F.; Visai, L. Int. J. Artif. Organs 2010, 33 (9), 636-645.

(21) Schastak, S.; Ziganshyna, S.; Gitter, B.; Wiedemann, P.; Claudepierre, T. PLOS ONE 2010, $5(7), \mathrm{e} 11674$.

(22) Simonetti, O.; Cirioni, O.; Orlando, F.; Alongi, C.; Lucarini, G.; Silvestri, C.; Zizzi, A.; Fantetti, L.; Roncucci, G.; Giacometti, A.; Offidani, A.; Provinciali, M. Br. J. Dermatol. 2011, 164 (5), 987-995.

(23) Caruso, E.; Banfi, S.; Barbieri, P.; Leva, B.; Orlandi, V. T. J. Photochem. Photobiol. B 2012, 114, 44-51.

(24) Dosselli, R.; Tampieri, C.; Ruiz-González, R.; De Munari, S.; Ragàs, X.; Sánchez-García, D.; Agut, M.; Nonell, S.; Reddi, E.; Gobbo, M. J. Med. Chem. 2013, 56 (3), 1052-1063.

(25) Choi, S.-K.; Park, S.-Y.; Kim, R.; Kim, S.-B.; Lee, C.-H.; Kim, J. F.; Park, S.-H. J. Bacteriol. 2009, 191 (10), 3350-3358.

(26) Kadar, B.; Kocsis, B.; Nagy, K.; Szabo, D. Curr. Med. Chem. 2013, 20 (30), 3759-3773.

(27) Zavascki, A. P.; Goldani, L. Z.; Li, J.; Nation, R. L. J. Antimicrob. Chemother. 2007, 60 (6), 1206-1215.

(28) Velkov, T.; Roberts, K. D.; Thompson, P. E.; Li, J. Future Med. Chem. 2016, 8 (10), 10171025.

(29) Dall, C. US first: E coli resistant to both colistin, carbapenems http://www.cidrap.umn.edu/news-perspective/2016/08/us-first-e-coli-resistant-bothcolistin-carbapenems (accessed Feb 15, 2017).

(30) Yin, R.; Hamblin, M. Curr. Med. Chem. 2015, 22 (18), 2159-2185.

(31) Hamblin, M. R.; O’Donnell, D. A.; Murthy, N.; Rajagopalan, K.; Michaud, N.; Sherwood, M. E.; Hasan, T. J. Antimicrob. Chemother. 2002, 49 (6), 941-951.

(32) Tomé, J. P. C.; Neves, M. G. P. M. S.; Tomé, A. C.; Cavaleiro, J. A. S.; Soncin, M.; Magaraggia, M.; Ferro, S.; Jori, G. J. Med. Chem. 2004, 47 (26), 6649-6652. 
(33) Sharma, M.; Visai, L.; Bragheri, F.; Cristiani, I.; Gupta, P. K.; Speziale, P. Antimicrob. Agents Chemother. 2008, 52 (1), 299-305.

(34) Nitzan, Y.; Gutterman, M.; Malik, Z.; Ehrenberg, B. Photochem. Photobiol. 1992, 55 (1), 89-96.

(35) Dosselli, R.; Ruiz-González, R.; Moret, F.; Agnolon, V.; Compagnin, C.; Mognato, M.; Sella, V.; Agut, M.; Nonell, S.; Gobbo, M.; Reddi, E. J. Med. Chem. 2014, 57 (4), 14031415.

(36) Liu, F.; Soh Yan Ni, A.; Lim, Y.; Mohanram, H.; Bhattacharjya, S.; Xing, B. Bioconjug. Chem. 2012, 23 (8), 1639-1647.

(37) Deris, Z. Z.; Swarbrick, J. D.; Roberts, K. D.; Azad, M. A. K.; Akter, J.; Horne, A. S.; Nation, R. L.; Rogers, K. L.; Thompson, P. E.; Velkov, T.; Li, J. Bioconjug. Chem. 2014, 25 (4), 750-760.

(38) Xu, W.-L.; Cui, A.-L.; Hu, X.-X.; You, X.-F.; Li, Z.-R.; Zheng, J.-S. Tetrahedron Lett. 2015, 56 (33), 4796-4799.

(39) Azad, M. A. K.; Yun, B.; Roberts, K. D.; Nation, R. L.; Thompson, P. E.; Velkov, T.; Li, J. Antimicrob. Agents Chemother. 2014, 58 (10), 6337-6338.

(40) Velkov, T.; Thompson, P. E.; Nation, R. L.; Li, J. J. Med. Chem. 2010, 53 (5), 1898-1916.

(41) Kanazawa, K.; Sato, Y.; Ohki, K.; Okimura, K.; Uchida, Y.; Shindo, M.; Sakura, N. Chem. Pharm. Bull. (Tokyo) 2009, 57 (3), 240-244.

(42) Hermanson, G. T. In Bioconjugate Techniques (Third edition); Academic Press: Boston, 2013; pp 229-258.

(43) Hermanson, G. T. In Bioconjugate Techniques (Third edition); Academic Press: Boston, 2013; pp 127-228.

(44) Díaz-Mochón, J. J.; Bialy, L.; Bradley, M. Org. Lett. 2004, 6 (7), 1127-1129.

(45) Little, R. G.; Anton, J. A.; Loach, P. A.; Ibers, J. A. J. Heterocycl. Chem. 1975, 12 (2), 343-349.

(46) Saohin, W. Studies on the stability and activity of polymyxin B solutions. PhD thesis, Robert Gordon University: United Kingdom, 1997.

(47) Taylor, R. B.; Richards, R. M. E.; Low, A. S.; Hardie, L. Int. J. Pharm. 1994, 102, $201-$ 206.

(48) Lakowicz, J. R. Principles of Fluorescence Spectroscopy; Springer Science \& Business Media, 2007.

(49) Redmond, R., W.; Gamlin, J., N. Photochem. Photobiol. 1999, 70 (4), 391-475.

(50) Schweitzer, C.; Schmidt, R. Chem. Rev. 2003, 103 (5), 1685-1758.

(51) Wilkinson, F.; Helman, W. P.; Ross, A. B. J. Phys. Chem. Ref. Data 1995, 24 (2), 6631021.

(52) Ogilby, P. R.; Foote, C. S. J. Am. Chem. Soc. 1983, 105 (11), 3423-3430. 